\title{
Oral glucosamine and chondroitin sulfate on synovial fluid biomarkers from osteoarthritic equine joints
}

\author{
Juliana Junqueira Moreira ${ }^{1}$ iD Joyce Martins Coelho ${ }^{1}$ Thais Sodré Lima Machado ${ }^{1}$ \\ Ana Paula Lopes Morais ${ }^{1}$ Yara Maria Michelacci ${ }^{2}$ Raquel Yvonne Arantes Baccarin ${ }^{3 *}$ iD
}

${ }^{1}$ Programa de Pós-graduação em Ciências, Faculdade de Medicina Veterinária e Zootecnia, Universidade de São Paulo (USP), São Paulo, SP, Brasil.

${ }^{2}$ Departamento de Bioquímica, Escola Paulista de Medicina, Universidade Federal de São Paulo (UNIFESP), São Paulo, SP, Brasil.

${ }_{3}^{3}$ Departamento de Clínica Médica, Faculdade de Medicina Veterinária e Zootecnia, Universidade de São Paulo (USP), 05508-270, São Paulo, SP, Brasil. E-mail: baccarin@usp.br. "Corresponding author.

ABSTRACT: Several studies, mainly in vitro, have shown that chondroitin sulfate (CS) and glucosamine (GlcN) do have chondro protective and anti-inflammatory actions. The aim of the present study was to investigate whether oral CS/GlcN supplementation has effects on the $C S$, hyaluronic acid $(H A)$ and prostaglandin $E_{2}\left(P G E_{2}\right)$ concentrations on synovial fluid of equine osteoarthritic joints. Horses with mild osteoarthritis $(O A)$ in tibiotarsal joint received daily PO doses of CS and GlcN (2.8/3.1 g) for 25 days. Synovial fluid (SF) and urine samples were collected before treatment (day 0), and every 7 days, until day 55 (30 days after the end of treatment). Urinary CS increased upon oral treatment, indicating that this compound was systemically distributed. Concerning the SF, CS concentration increased after the end of the treatment and returning to baseline afterwards, while $H A$ and $P G E_{2}$ concentrations did not change. Despite the systemic distribution, oral supplementation of CS/GlcNfor 25 days was insufficient as an anti-inflammatory support. However, it is possible to infer that there was an anabolic effect upon cartilage matrix.

Key words: chondroitin sulfate, horse, glucosamine, osteoarthritis, synovial fluid.

Efeitos da glucosamina e condroitim sulfato oral sobre biomarcadores do líquido sinovial de articulações osteoartríticas de equinos

RESUMO: Vários estudos, principalmente in vitro, têm mostrado que o condroitim sulfato (CS) e a glucosamina (GLcN) possuem ação condroprotetora e anti-inflamatória. O objetivo deste trabalho foi investigar se a administração oral de CS/GLcN possui efeito sobre as concentrações de CS, ácido hialurônico (AH) e prostaglandina $E_{2}\left(P G E_{2}\right)$ do liquido sinovial (LS) de articulações equinas com osteoartrite (OA). Cavalos diagnosticados com OA tibiotársica grau leve receberam por via oral doses diárias de CS e GlcN (2,8g/3,1g) por 25 dias. Amostras de LS e urina foram coletadas antes do tratamento (dia 0) e a cada 7 dias até o dia 55 (30 dias após o fim do tratamento). Houve aumento do CS urinário, indicando a distribuição sistêmica desse composto. No LS, a concentração de CS aumentou após o final do tratamento e retornou aos valores basais em seguida, enquanto as concentrações de HA e PGE, não apresentaram alterações. Apesar da distribuição sistêmica, a suplementação oral de CS/GlcNpor 25 dias foi insuficiente como medida anti-inflamatória. Contudo, pode-se inferir que houve efeito anabólico sobre a matriz cartilagínea.

Palavras-chave: cavalo, condroitim sulfato, glucosamina, liquido sinovia, osteoartrite.

\section{INTRODUCTION}

Nonsteroidal anti-inflammatory drugs (NSAIDs) remain the treatment of choice for most cases of equine lameness, because of the undisputable analgesic effect of many of these drugs. In cases of chronic pain, such as osteoarthritis (OA), wherein the equine patient requires ongoing, daily pharmaceutical support to maintain functionality and quality of life, the use of NSAIDs is limited by its potential side effects, which may include gastric ulceration and renal functions changes (REED et al., 2006; RAIDAL et al., 2014). This led to the development of "alternative" or "complementary" treatments for chronic cases.

Currently, there are no disease-modifying therapies with strong evidence of efficacy in equine $\mathrm{OA}$; therefore, its management is based on relieving symptoms and improving functions. Common therapies for joint diseases are intra-articular (IA) injections of corticosteroid, with or without hyaluronic acid (HA); polyacrylamide hydrogel 
(PAAG); blood-derived products such as platelet-rich plasma (PRP), autologous conditioned serum (ACS), autologous processed plasma; and mesenchymal stem cell (MSC). Corticosteroid provides better pain relief and functionality in the short- and medium-term, but over again alternatives are needed for older horses and horses with chronic OA. The IAHA alone is often not enough to decrease lameness substantially; although, its greatest benefit may be its long-term disease-modifying effects (CONTINO, 2018). The PAAG is used with promising results, which studies showed alleviates lameness and joint effusion in osteoarthritic horse joints (TNIBAR et al., 2015); however, this treatment requires further investigation.

Most equine clinical studies have shown that PRP has positive effects when used to treat joint injuries; however, these studies have a high risk of bias and PRP products vary greatly in composition, making it difficult to compare their efficacies (BROSSI et al., 2015). The most common ACS used on horses is called IRAP, and it is superior to corticosteroids in treating joint disease with a concurrent soft tissue injury (CONTINO, 2018). Several studies have shown that intra-articular mesenchymal stem cell (MSC) injection helps to reduce synovial inflammation and results in better cartilage repair, when compared to other currently available therapies and surgical techniques; however, production of hyaline tissue have yet to be achieved (ORTVED; NIXON, 2016)

Finally, systemic therapy with HA, polysulfated glycosaminoglycans (PSGAG), pentosanpolysulfatesodium(PPS)and bisphosphonates as well as other therapies such as shockwave and physical therapy are indicated in the management and treatment of joint disease (CONTINO, 2018).

One of the main components of the cartilage extracellular matrix, responsible for many of its properties, is the proteoglycan aggrecan, which is composed by a $\sim 200 \mathrm{kDa}$ protein core, glycosylated with chondroitin sulfate $(\mathrm{CS}, \sim 100)$ and keratan sulfate (KS, 30) side chains. Thus, CS is a prominent component of the cartilage matrix (WATANABE, 1998).

Under normal conditions, rates of proteoglycan synthesis and degradation are in equilibrium, while in OA the degradative processes take prevalence, and it was believed that CS and/ or glucosamine $(\mathrm{GlcN})$ could provide substrates to increase the proteoglycan synthesis and cartilage regeneration. Thus, in the 1990's, CS and GlcN were introduced as "nutraceutical agents" for treatment of OA. Their efficacy in OA were demonstrated in a number of clinical trials (McALINDONet al., 2000; VANGSNESS et al., 2009), and several in vitro studies have shown that CS and GlcNdo have chondroprotective and anti-inflammatory actions (BASSLEER et al., 1998; CHAN et al., 2005; VALLIÈRES \& DU SOUICH, 2010; HARLAN et al., 2012).

However, beneficial effects of CS/GlcNoral administration in horses are still controversial. When CS is administered orally, presumably, the intact CS molecules are degraded by gastrointestinal enzymes and subjected to a large first-pass effect in the liver, reaching the systemic circulation at lower concentrations than in vitro studies, compromising the efficacy of its chondro protective and antiinflammatory properties (WELCH et al., 2012; HIGLER et al., 2014).

$\mathrm{CS}$ and GlcN are currently recommended for humans as a "SYSADOA" - Symptomatic SlowActing Drug for the treatment of OA. It means that they provide pain relief and increased joint mobility only after a relatively long period of regular administration (1-2 months), and their effects last long after the end of treatment (6-9 months) (MORITA et al., 2018).

Studies in horses have shown that CS and GlcN are more effective in improving cartilage metabolism when in association (LAVERTY et al., 2005; RODGERS, 2006; BACCARIN et al., 2012). Nowadays, numerous oral supplements containing GlcN and CS, together with other nutrients, are commercially available (RAMEY et al., 2002). These preparations are known as Disease-Modifying Osteo Arthritis Drugs (DMOADs).

The aim of the present study was to investigate the effects of oral administration of CS and GlcNon synovial fluid $\mathrm{CS}, \mathrm{HA}$ and prostaglandin $\mathrm{E}_{2}\left(\mathrm{PGE}_{2}\right)$ concentrations in horses with mild OA. The hypothesis is that these compounds have anti-inflammatory and chondro protective activities that would be useful in the management of joint diseases in horses.

\section{MATERIALS AND METHODS}

This study was approved by the Ethic Committee on Animal Use of the School of Veterinary Medicine and Animal Science of the University of São Paulo - CEUA/USP (949/2006).

\section{Animals}

Horses were submitted to clinical and radiographic evaluation for inclusion criteria: lameness due to OA in the tibiotarsal joint (grade 1-5) with or without joint effusion; radiographic lesions compatible 
with OA type 1 or 2 , according to McILWRAITH (2002); no prior or current treatment with CS, glucosamine $(\mathrm{GlcN})$, and/or anti-inflammatory drugs.

Six horses, aged 6-10 years old, weighing $350-450 \mathrm{~kg}$, were diagnosed as mild osteoarthritis (OA) in one of the tibiotarsal joint and were selected to be included in the study. At that time, they were subjected to similar exercise and nutritional managements (pellets, coast cross hay and water ad libitum).

\section{Treatment}

Osteoarthritic horses received daily 30 g-doses, PO, of CS/GlcN supplement for 25 days. The oral CS/GlcN supplement used in the study provided active ingredients of $2800 \mathrm{mg}$ CS and 3100 $\mathrm{mg}$ GlcN per dose (30 g scoop) (HIGLER et al., 2014). The supplement also contained amino acids (L-methionine, Met; L-lysine, Lys), and minerals (sulfur, selenium, manganese, copper, and zinc). Before use, this preparation was analyzed for CS and GIcN (DIETRICH \& DIETRICH, 1976; GIUSTI et al., 1988), which have shown that the concentrations stated by the manufacturer were correct. No other intramuscular, intravenous or topical therapies were administered during this time.

Urine and SF samples were collected the day before initiation of treatment (day 0 ), and on days $7,14,21$ of treatment, as well as on days 28,35 , 42, 49 and 55 post-treatment (up to 30 days after the end of treatment). All urine samples were collected via urethral catheterization or natural urination. The arthrocentesis was performed medially to the saphenous vein, just below the medial malleolus of the tibia, in the dorsomedial face of the tarsus (STASHAK, 2002). All SF and urine samples were centrifuged to remove debris $\left(2000 \times \mathrm{g}, 15 \mathrm{~min}, 4^{\circ} \mathrm{C}\right)$, and the supernatants were aliquoted and stored at $-80^{\circ} \mathrm{C}$.

\section{Urinary Glycosaminoglycans}

Urinary glycosaminoglycans were isolated from urine samples by ion exchange chromatographyas previously described (VIEIRA et al., 2005). These compounds were identified by agarose gel electrophoresis in $0.05 \mathrm{M}$ 1,3-diaminopropaneacetate buffer, pH 9 (PDA) buffer (DIETRICH \& DIETRICH, 1976), and quantified by densitometry of the gel slabs. Urinary creatinine was measured by the alkaline picrate method in automatic biochemical analyzer (HEINEGÅRD \&TIDERSTRÖM, 1973).

\section{Synovial Fluid Glycosaminoglycans and $P G E_{2}$}

$\mathrm{HA}$ and $\mathrm{CS}$ concentrations were determined as previously described (MACHADO et al., 2012). In brief, synovial fluid (SF) samples (50 $\mu \mathrm{L})$ were submitted to proteolysis with maxatase solution $(4 \mathrm{mg} / \mathrm{mL}$ in $0.05 \mathrm{~mol} / \mathrm{L}$ Tris-Hcl, $\mathrm{pH}$ 8.0, $100 \mu \mathrm{L})$. After overnight incubation at $50{ }^{\circ} \mathrm{C}$, maxatase was heat inactivated $\left(10 \mathrm{~min}, 100^{\circ} \mathrm{C}\right)$, and debris were removed by centrifugation $(3000 \times \mathrm{g}$ for $15 \mathrm{~min}$ at $24^{\circ} \mathrm{C}$ ). The supernatant was freeze dried, and re-suspended in distilled water $(25 \mu \mathrm{L})$. Aliquots $(5 \mu \mathrm{L})$ were submitted to agarose gel electrophoresis in PDA buffer, and stained with $0.1 \%$ Toluidine Blue in 50\% ethanol: $1 \%$ acetic acid (for sulfated glycosaminoglycans), and then in $0.05 \mathrm{M}$ sodium acetate buffer, $\mathrm{pH} 5$ (for HA). Compounds were quantified by densitometry of the agarose gel slabs.

$\mathrm{PGE}_{2}$ was quantified by ELISA, using a commercial PGE, EIA kit (Monoclonal Antibody, Cayman Chemical Company, USA) (PRADELLES et al., 1985), and adapted to horse SF by BACCARIN et al. (2014). To check for possible dilution of the SF samples due to effusion, urea concentrations were measured by urease-glutamate dehydrogenase method, using an automatic biochemical analyzer. $\mathrm{PGE}_{2}, \mathrm{HA}$ and $\mathrm{CS}$ are given as concentrations.

\section{Statistical analysis}

Data were evaluated for normality using the Kolmogorov-Smirnov test. Afterwards, the unpaired $\mathrm{t}$ tests and ANOVA followed by Tukey-Kramer test were used to compare time points. Graph Pad Instat 3 software was used to perform the statistical analysis. Statistical significance was set at a $\mathrm{p}<0.05$.

\section{RESULTS}

All six horses, initially, presented, lameness (scores 1-3). Two of these animals (\#2 and \#4) also presented joint effusion. Upon treatment with $\mathrm{CS}+\mathrm{GlcN}$, the lameness of five animals improved; although, the differences were not statistically significant. One horse maintained its initial lameness score (\#3), and one (\#2) maintained joint effusion. Others clinical signs of osteoarthritis were not observed at the beginning of the trial and the physical exams did not change after $\mathrm{CS}+\mathrm{GlcN}$ administration.

The CS increased in the urine compared to baseline values during the treatment (days 7 and 14, $\mathrm{P}<0.05$ ), possibly due to the excretion of exogenous CS (Figure 1). This finding showed the systemic distribution of the CS given PO.

Concerning the SF (Figure 2), CS concentration increased after the end of treatment (days 28; $\mathrm{P}<0.01$ and 35; $\mathrm{P}<0.05$ ), returning to baseline afterwards. In contrast, the SF HA concentrations did 


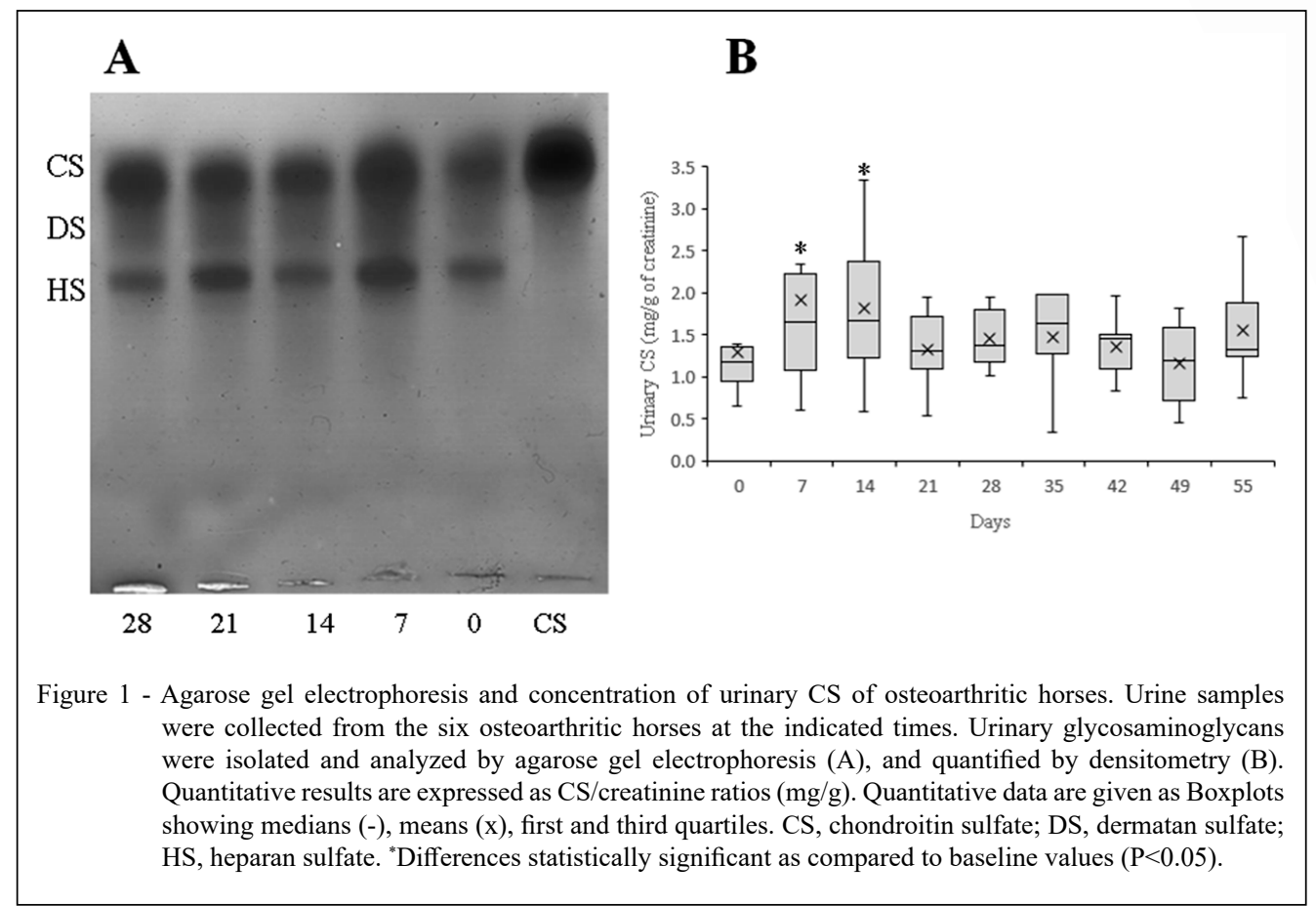

not vary during all the experimental period (treatment and post-treatment).

Concerning $\mathrm{PGE}_{2}$ concentrations, no variations were observed (Figure 3) $(\mathrm{P}>0.05)$. In all figures the data points are presented relative to time 0 .

\section{DISCUSSION}

VIEIRA et al. (2005) reported that urinary $\mathrm{CS}$ and KS reflect the turnover rates of cartilage proteoglycans, and BACCARIN et al. (2012) have shown that treatment with CS and GlcN (given every 5 days by IM route, 25 days) led to a long lasting increase in the urinary CS and KS, and significantly improved the OA clinical signs. In the present study, $\mathrm{CS}$ and GlcN were given PO every day, per 25 days.

Despite the higher doses of CS and GlcN (PO: $2.85 \mathrm{~g}$ CS and $3.15 \mathrm{~g}$ GlcN/day; IM: $0.75 \mathrm{~g} \mathrm{CS}$ and $0.75 \mathrm{~g}$ GlcN every 5 days), the urinary CS did not reach the levels obtained upon IM administration (13 $\mathrm{mg} / \mathrm{g}$ of creatinine). This suggested that less intact CS reached the urine. It is not surprising that the bioavailability of CS given PO is lower (2232\%) (DU et al., 2004; LAVERTY et al., 2005; MEULYZER et al., 2008), but it is also possible that the CS degradation products are effective as chondro protectors and/or anti-inflammatory agents (WELCH et al., 2012). In dogs, the bioavailability of oral CS is 5\%; however, it reaches $200-278 \%$ when multiple doses are offered (ADEBOWALE et al., 2002). RODGERS (2006) reported that oral administration of CS and GlcN (1.2 g/3.9 g twice daily) during 8 years in OA horses dramatically decreased the frequency and number of intra-articular infiltrations of HA and/or corticosteroids. Additionally, according RODGERS (2006) sustained oral dosing of CS may result in significantly higher measurable joint levels that would correlate with the beneficial effects on cartilage seen in the in vitro studies.

Results of others studies using oral $\mathrm{CS}+\mathrm{GlcN}$ supplement have varied; no beneficial effects were observed in stride length of aged horses after three months supplementation (HIGLER et al., 2014), in contrast stride characteristics (joint motion, stride length and swing duration) were improved in veteran horses after 12 weeks of oral $\mathrm{CS}+\mathrm{GlcN}$ supplementation (FORSYTH et al., 2006).

As already mentioned, the transitory increase in urinary CS upon treatment is possibly due to exogenous CS, but the SF CS is not, since it increased after the end of treatment. The CS and GlcN have been shown in vitro to increase the proteoglycans and glycosaminoglycans(GAGs) synthesis (BASSLEER et al., 1998; LEGENDRE 


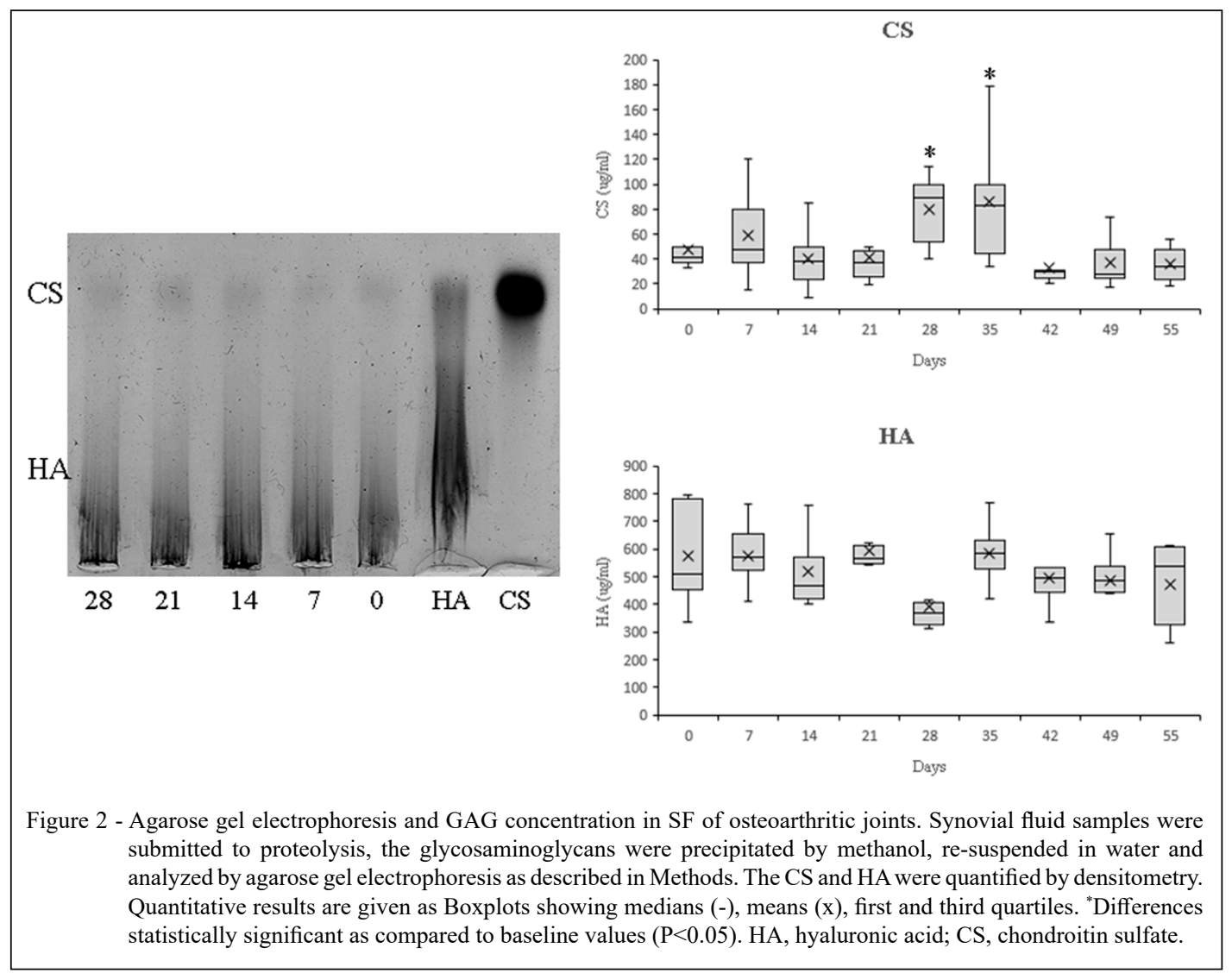

et al., 2008). Therefore, it is possible that oral CS/ GlcN administration for 25 days has stimulated the synthesis of CS by the cartilage matrix, suggesting anabolic effects.
Repeated arthrocentesis was reported as a potential confounding factor for the use of synovial $\mathrm{PGE}_{2}$ and GAG concentrations as markers of joint disease. However, based on VAN DEN BOOM et

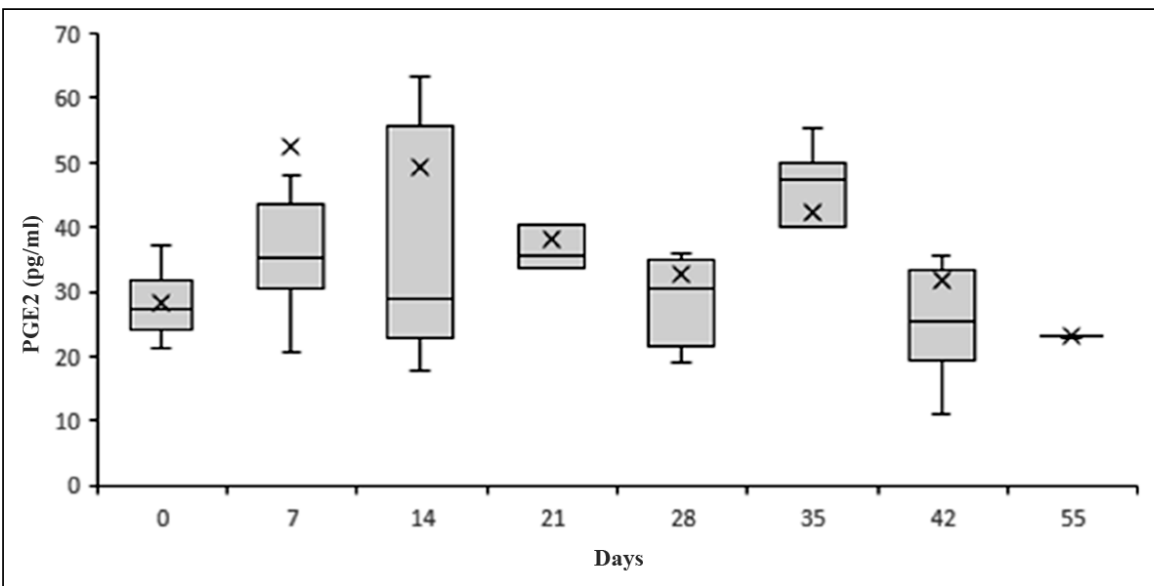

Figure 3 - PGE2 in SF of osteoarthritic joints. PGE2 was measured in the synovial fluid of osteoarthritic horses before (day 0), during (days 7, 14,21), and after 25 days of oral supplement treatment (day 55). Quantitative results are given as Boxplots showing medians.

$(-)$, means (x), first and third quartiles. *Differences statistically significant as compared to baseline values $(\mathrm{P}<0.05)$. 
al. (2005) study, such a confounding effect can be avoided if one week or more separates punctures. The SF $\mathrm{HA}$ and $\mathrm{PGE}_{2}$ concentration did not vary during all the experimental period; although, in vitro studies have shown that GlcN alone or in combination with $\mathrm{CS}$ has the potential to reduce $\mathrm{PGE}_{2}$ levels (CHAN et al., 2005). In addition, it has been shown that CS and GlcN increase the concentration and improve the composition of hyaluronic acid, which may play a role in its anti-inflammatory effects (TRUMBLE, 2005).

The oral supplement used in this study was a $\mathrm{CS} / \mathrm{GlcN}$ combination that delivered $2.8 \mathrm{~g} \mathrm{CS} / 3.1 \mathrm{~g}$ GlcN (active ingredients) per dose. This gives a total daily dose of $5.9 \mathrm{~g}$ of active $\mathrm{CS} / \mathrm{GlcN}$ for a typical 450-kg horse for 25 days. Our results suggested that long-term use of a PO CS/GlcN supplement is necessary to decrease $\mathrm{PGE}_{2}$ concentrations in SF.

\section{CONCLUSION}

Oral supplementation with CS increased urinary $\mathrm{CS}$ in horses with mild OA, indicating that this compound was systemically distributed. Although, the oral supplement containing CS + GlcN (25 days) has led to synovial fluid CS concentration transient increase, suggesting anabolic effects, no anti-inflammatory effects were observed.

\section{ACKNOWLEDGMENT}

This research was supported by grant from Coordenação de Aperfeiçoamento de Pessoal de Nível Superior - Brazil (CAPES) - Finance code 001. This sponsor did not have any influence on the study design or on the data collection, analysis and interpretation.

\section{BIOETHICS AND BIOSSECURITY COMMITTEE APPROVAL}

Protocol no 949/2006.

\section{DECLARATION OF CONFLICT OF INTERESTS}

The authors declare no conflict of interest. The founding sponsors had no role in the design of the study; in the collection, analyses, or interpretation of data; in the writing of the manuscript, and in the decision to publish the results.

\section{AUTHORS' CONTRIBUTIONS}

RYAB, JMC and YMM conceived and designed experiments. JMC, TSLM, APLM performed the experiments. RYAB, JMC and YMM carried out the lab analyses. JJM and RYAB prepared the draft of the manuscript. JJM, RYAB and YMM critically revised the manuscript. All authors approved of the final version.

\section{REFERENCES}

ADEBOWALE, A. et al. The bioavailability and pharmacokinetics of glucosamine hydrochloride and low molecular weight chondroitin sulfate after single and multiple doses to beagle dogs. Biopharmeutics and Drug Disposition, v.23, p.217-225, 2002.

BACCARIN, R.Y. et al. Urinary glycosaminoglycans in horse osteoarthritis. Effects of chondroitin sulfate and glucosamine. Research Veterinary Science, v.93, p.88-96, 2012. Available from: <https://www.sciencedirect.com/science/article/abs/pii/ S0034528811003481?via\%3Dihub>. Accessed: Feb. 28, 2018. doi: 10.1016/j.rvsc.2011.08.009.

BACCARIN, R.Y. et al. Relevance of synovial fluid chondroitin sulphate as a biomarker to monitor polo pony joints. Canadian Journal of Veterinary Research, v.78, p.50-60, 2014. Available from: <https://www.ncbi.nlm.nih.gov/pmc/articles/ PMC3878009/>. Accessed: Feb. 28, 2018.

BASSLEER C.T. et al.Stimulation of proteoglycan production by glucosamine sulfate in chondrocytes isolated from human osteoarthritic articular cartilage in vitro. Osteoarthritis and Cartilage, v.6, p.427-434, 1998. Available from: $<$ https://www.sciencedirect.com/science/article/pii/ S1063458498901467?via\%3Dihub>. Accessed: Feb. 28, 2018. doi: 10.1053/joca.1998.0146.

BROSSI P.M. et al. Platelet-rich plasma in orthopedic therapy: a comparative systematic review of clinical and experimental data in equine and human musculoskeletal lesions. BMC Veterinary Research, v.11, p.98, 2015. Available from: <https://bmcvetres. biomedcentral.com/articles/10.1186/s12917-015-0403-z>. Accessed: Nov. 07, 2018. doi: 10.1186/s12917-015-0403-z.

CHAN P.S. et al. Glucosamine and chondroitin sulfate regulate gene expression and synthesis of nitric oxide and prostaglandin $\mathrm{E}(2)$ in articular cartilage explants. Osteoarthritis and Cartilage, v.13, p.387- 394, 2005. Available from: <https://www.sciencedirect. com/science/article/pii/S1063458405000191?via\%3Dihub>. Accessed: Feb. 28, 2018. doi: 10.1016/j.joca.2005.01.003.

DIETRICH, C.P.; DIETRICH, S.M. Electrophoretic behaviour of acidic mucopolysaccharides in diamine buffers. Analytical Biochemistry, v.70, p.645-647, 1976. Available from: <https:// www.sciencedirect.com/science/article/pii/0003269776904966>. Accessed: Feb. 28. 2018. doi: 10.1016/0003-2697(76)90496-6.

DU, J. et al. The bioavailability and pharmacokinetics of glucosamine hydrochloride and chondroitin sulfate oral and intravenous single dose after administration in the horse. Biopharmaceutics \& Drug Disposition, v.25, p.109-116, 2004. Available from: <http:// onlinelibrary.wiley.com/doi/10.1002/bdd.392/abstract $>$. Accessed: Feb. 28, 2018. doi: 10.1002/bdd.392.

FORSYTH, R.K. et al. Double blind investigation of the effects of oral supplementation of combined glucosamine hydrochloride (HCSG) and chondroitin sulphate (CS) on stride characteristics of veteran horses. Equine Veterinary Journal, v.36, p.622625, 2006. Available from: <https://onlinelibrary.wiley.com/doi/ epdf/10.1111/j.2042-3306.2006.tb05615.x>. Accessed: Feb. 28, 2018. doi: 10.1111/j.2042-3306.2006.tb05615.x.

GIUSTI, E.P. et al. Horse urinary kallikrein, I. Complete purification and characterization. Biological Chemistry HoppeSeyler, v.369, p.387-396, 1988. 
HARLAN, R.S. et al. The effect of glucosamine and chondroitin on stressed equine cartilage explants. Journal of Equine Veterinary Science, v.32, p.12-14, 2012. Available from: <https://www. sciencedirect.com/science/article/pii/S0737080611003868>. Accessed: Feb. 28, 2018. doi: 10.1016/j.jevs.2011.06.005.

HEINEGÅRD, D.; TIDERSTRÖM, G. Determination of serum creatinine by a direct colorimetric method. Clinica Chimica Acta; International Journal of Clinical Chemistry, v.43, p.305-310, 1973. Available from: <https://www.sciencedirect.com/science/ article/pii/000989817390466X?via\%3Dihub>. Accessed: Feb. 28, 2018. doi: 10.1016/0009-8981(73)90466-X

HIGLER, M. H. et al. The effects of three-month oral supplementation with a nutraceutical and exercise on the locomotor pattern of aged horses. Equine Veterinary Journal, v.46, p.611-617, 2014. Available from: < http://onlinelibrary.wiley. com/doi/10.1111/evj.12182/abstract;jsessionid=2C3FD2B7FBE D47C178BD47E1D9AD3162.f01t03>. Accessed: Feb. 28, 2018. doi: $10.1111 /$ evj.12182.

LAVERTY, S. et al. Synovial fluid levels and serum pharmacokinetics in the large animals model following treatment with oral glucosamine at clinically relevant doses. Arthritis and Rheumatism, v.52, p.181-191, 2005. Available from: $<$ http://onlinelibrary.wiley.com/doi/10.1002/art.20762/abstract $>$. Accessed: Feb. 28, 2018. doi: 10.1002/art.20762.

LEGENDRE, F. et al. Chondroitin sulfate modulation of matrix and inflammatory gene expression in IL-1betastimulated chondrocytes--study in hypoxic alginate bead cultures. Osteoarthritis and Cartilage, v.16, p.105-114, 2008. Available from: <https://www.sciencedirect.com/ science/article/pii/S1063458407002002>. Accessed: Feb. 28, 2018. doi: 10.1016/j.joca.2007.05.020.

MACHADO, T. S. Synovial fluid chondroitin sulfate Indicates abnormal joint metabolism in asymptomatic osteochondritic horses. Equine Veterinary Journal, v.44, p.404-411, 2012 Available from: <http://onlinelibrary.wiley.com/doi/10.1111/j.20423306.2011.00539.x/abstract $>$. Accessed: Feb. 28, 2018. doi: 10.1111/j.2042-3306.2011.00539.x.

McALINDON, T. E. et al. Glucosamine and chondroitin for treatment of osteoarthritis: a systematic quality assessment and meta-analysis. JAMA, v.283, p.1469-1475, 2000. Available from: $<$ https://jamanetwork.com/journals/jama/fullarticle/192498>. Accessed: Feb. 28, 2018. doi: 10.1001/jama.283.11.1469.

McILWRAITH, C.W. Diseases of Joints, Tendons, Ligaments, and Related Structures. In: STASHAK, T.S. Adam's lameness in horses. Philadelphia: Lippincott Williams \& Wilkins, 2002. p. $459-644$

MEULYZER, M. et al. Comparison of pharmacokinetics of glucosamine and synovial fluid levels following administration of glucosamine sulphate hydrochloride or glucosamine. Osteoarthritis and Cartilage, v.16, p.973-979, 2008. Available from: <https://linkinghub.elsevier.com/retrieve/ pii/S1063-4584(08)00004-6>. Accessed: Feb. 28, 2018. doi: 10.1016/j.joca.2008.01.006.

MORITA, M. et al. Efficacy of Chondroitin Sulfate for Painful Knee Osteoarthritis: A One-Year, Randomized, DoubleBlind, Multicenter Clinical Study in Japan. Biological \& Pharmceutical Bulletin, v.41, p.163-171, 2018. Available from: <https://www.jstage.jst.go.jp/article/bpb/41/2/41_b1700556/_article>. Accessed: Feb. 28, 2018. doi: 10.1248/bpb. b17-00556.

ORTVED K. F.; NIXON A. J. Cell-based cartilage repair strategies in the horse. Veterinary Journal, v.208, p.1-12, 2016. Available from: <https://www.sciencedirect.com/science/article/ pii/S1090023315004360?via\%3Dihub>. Accessed: Nov. 07, 2018. doi: 10.1016/j.tvj1.2015.10.027.

PRADELLES, P. et al. Enzyme immunoassays of eicosanoids using acetylcholine esterase the label: an alternative to radioimmunoassay. Analytical Chemistry, v.57, p.1170-1173, 1985. Available from: $<$ https://pubs.acs.org/doi/abs/10.1021/ac00284a003>. Accessed: Feb. 28, 2018. doi: 10.1021/ac00284a003.

RAIDAL, S. L. et al. Effects of meloxicam and phenylbutazone on renal responses to furosemide, dobutamine, and exercise in horses. American Journal of Veterinary Research, v.75, p.668-679, 2014. Available from: <https://avmajournals.avma. org/doi/abs/10.2460/ajvr.75.7.668?url_ver=Z39.88-2003\&rfr id $=$ ori $\% 3$ Arid $\% 3$ Acrossref.org $\& \mathrm{rfr}$ dat $=$ cr pub\%3Dpubmed $>$. Accessed: Feb. 28, 2018. doi: 10.2460/ajvr.75.7.668.

RAMEY, D. W. et al. An analysis of glucosamine and chondroitin sulfate content in oral joint supplement products. Journal of Equine Veterinary Science, v.22, p.125-127, 2002. Available from: $<$ https://www.sciencedirect.com/science/ article/pii/S0737080602701251>. Accessed: Feb. 28, 2018. doi: 10.1016/S0737-0806(02)70125-1.

REED, S.K. et al. Effects of phenylbutazone alone or in combination with flunixinmeglumine on blood protein concentrations in horses. American Journal of Veterinary Research, v.67, p.398-402, 2006. Available from: <https://avmajournals.avma org/doi/abs/10.2460/ajvr.67.3.398?url_ver=Z39.88-2003\&rfr_ $\mathrm{id}=$ ori $\% 3$ Arid $\% 3$ Acrossref.org\&rfr_dat $=$ cr_pub\%3Dpubmed $>$. Accessed: Feb. 28, 2018. doi: 10.2460/ajvr.67.3.398.

RODGERS, M.R. Effects of oral glucosamine and chondroitin sulfates supplementation on frequency of intra-articular therapy of the horse tarsus. The International Journal of Applied Research in Veterinary Medicine, v.4, p.155-162, 2006. Available from: <http://jarvm.com/articles/Vol4Iss2/Rodgers. pdf $>$. Accessed: Feb. 28, 2018.

TNIBAR A. et al. An international multi-centre prospective study on the efficacy of an intraarticular polyacrylamide hydrogel in horses with osteoarthritis: a 24 months follow-up. Acta Veterinaria Scandinavia, v.57, p.20,2015. Available from: <https://actavetscand.biomedcentral.com/articles/10.1186/ s13028-015-0110-6>. Accessed: Nov. 07, 2018. doi: 10.1186/ s13028-015-0110-6.

TRUMBLE, T. N. The use of nutraceuticals for osteoarthritis in horses. The Veterinary Clinics of North America. Equine Practice, v.21, p.575-597, 2005. Available from: $<$ https://www.sciencedirect.com/science/article/pii/ S0749073905000532?via\%3Dihub>. Accessed: Feb. 28, 2018. doi: 10.1016/j.cveq.2005.08.004.

VALLIÈRES, M.; DU SOUICH, P.Modulation of inflammation by chondroitin sulfate. Osteoarthritis and Cartilage, v.18, p.S1-S6, 2010. Available from: <https://linkinghub.elsevier.com/retrieve/ pii/S1063-4584(10)00088-9>. Accessed: Feb. 28, 2018. doi: 10.1016/j.joca.2010.02.017. 
VAN DEN BOOM, R. et al. Influence of repeated arthrocentesis and exercise on synovial fluid concentrations of nitric oxide, prostaglandin $\mathrm{E}_{2}$ and glycosaminoglycans in healthy equine joints. Equine Veterinary Journal, v.37, p.250-256, 2005. Available from: $<\mathrm{http}: / /$ onlinelibrary.wiley.com/doi/10.2746/0425164054530740/abstract>. Accessed: Feb. 28, 2018. doi: 10.2746/0425164054530740.

VANGSNESS, C. T. et al. A review of evidence-based medicine for glucosamine and chondroitin sulfate use in knee osteoarthritis. Arthroscopy, v.25, p.86-94, 2009. Available from: <https://www.sciencedirect.com/science/ article/pii/S0749806308005896?via\%3Dihub>. Accessed: Feb. 28, 2018. doi: 10.1016/j.arthro.2008.07.020.

VIEIRA, F. A. C. Urinary excretion of glycosaminoglycans in horses: changes with age, training and osteoarthritis. Journal of Equine Veterinary Science, v.25, p.387-400, 2005. Available from: <https://www.sciencedirect.com/science/ article/pii/S073708060500376X>. Accessed: Feb. 28, 2018. doi: $10.1016 /$ j.jevs.2005.08.012.

WATANABE, H. Roles of aggrecan, a large chondroitin sulfate proteoglycan, in cartilage structure and function. Journal of Biochemistry, v.124, p.687-693, 1998. Available from: <https:// www.jstage.jst.go.jp/article/biochemistry1922/124/4/124_4_687/_ pdf/-char/en>. Accessed: Feb. 28, 2018.

WELCH, C.A. et al. Plasma concentration of glucosamine and chondroitin sulfate in horses after oral dose. Journal of Equine Veterinary Science, v.32, p.60-64, 2012. Available from: $<$ http:// www.j-evs.com/article/S0737-0806(11)00468-0/abstract $>$. Accessed: Feb. 28, 2018. doi: 10.1016/j.jevs.2011.08.004. 